EUROPEAN INDUSTRIAL POLICY AND COMPETITIVENESS 
Also by Thomas C. Lawton

Technology and the New Diplomacy: The Creation and Control of EC Industrial Policy for Semiconductors 


\section{EUROPEAN \\ INDUSTRIAL POLICY \\ AND \\ COMPETITIVENESS}

\section{CONCEPTS AND INSTRUMENTS}

Edited by Thomas C. Lawton

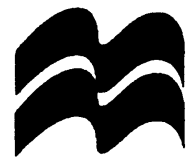




\section{MACMILLAN PRESS LTD}

Houndmills, Basingstoke, Hampshire RG21 6XS and London

Companies and representatives throughout the world

A catalogue record for this book is available from the British Library.

ISBN 978-0-333-74410-9 ISBN 978-1-349-27629-5 (eBook)
DOI 10.1007/978-1-349-27629-5

First published in the United States of America 1999 by

ST. MARTIN'S PRESS, INC.,

Scholarly and Reference Division,

175 Fifth Avenue, New York, N.Y. 10010

ISBN 978-0-312-22333-5

Library of Congress Cataloging-in-Publication Data

European industrial policy and competitiveness : concepts and

instruments / edited by Thomas C. Lawton.

p. $\mathrm{cm}$.

Results of a workshop in April 1998 funded by the School of

Management at Royal Holloway University of London, and a roundtable

conference at King's College London in late November, 1998.

Includes bibliographical references and index.

ISBN 978-0-312-22333-5 (cloth)

1. Industrial policy-European Union countries-Congresses.

2. Competition-European Union countries-Congresses. I. Lawton,

Thomas C.

HD3616.E823E94 1998

$338.94-\mathrm{dc} 21$

99-11255

CIP

Selection, editorial matter and Chapters 1,2 and 11 @ Thomas C. Lawton 1999

Individual chapters (in order) $\odot$ Wolf Sauter, Steven McGuire, Günter Walzenbach,

Claudio Radaelli, Christopher Bovis, Debra Johnson and Colin Turner, Jill Preston,

Thomas C. Lawton and Michael Hodges 1999

All rights reserved. No reproduction, copy or transmission of this publication may be made without written permission.

No paragraph of this publication may be reproduced, copied or transmitted save with written permission or in accordance with the provisions of the Copyright, Designs and Patents Act 1988, or under the terms of any licence permitting limited copying issued by the Copyright Licensing Agency, 90 Tottenham Court Road, London W1P 9HE.

Any person who does any unauthorised act in relation to this publication may be liable to criminal prosecution and civil claims for damages.

The authors have asserted their rights to be identified as the authors of this work in accordance with the Copyright, Designs and Patents Act 1988.

This book is printed on paper suitable for recycling and made from fully managed and sustained forest sources.

$\begin{array}{llllllllll}10 & 9 & 8 & 7 & 6 & 5 & 4 & 3 & 2 & 1\end{array}$

$\begin{array}{llllllllll}08 & 07 & 06 & 05 & 04 & 03 & 02 & 01 & 00 & 99\end{array}$ 
To the memory of Michael Robert Hodges

A scholar and a gentleman 


\section{Contents}

List of figures

xii

Foreword by Susan Strange

xiii

Acknowledgements

$\mathrm{XV}$

Glossary

xvii

Contributors

xxiii

Chapter 1 Introduction: concepts defined 1 and scenes set

Thomas C. Lawton

1.1 Introduction 1

1.2 Notions of competitiveness 3

1.3 The industrial policy debate 9

1.4 The EU industrial policy context 12

1.5 A European industrial competitiveness 17 model

Chapter 2 Fostering Invention and Innovation:

Europe's collaborative R\&TD initiatives

Thomas C. Lawton

2.1 Introduction 23

2.2 The many faces of European technology 24 policy

2.3 The origins of EU involvement in 26 research and development

2.4 The two-pronged approach 28

2.5 A change in technology policy's 39 context and content

2.6 Technology policy and competitiveness 42

2.7 Conclusions 44 
Chapter 3 EU Competition Rules: promoting and policing the Internal Market Wolf Sauter

3.1 Introduction 49

3.2 Compatibility between industrial and 50 competition policy

3.3 Competition policy and competitiveness $\quad 52$

3.4 Structure and instruments 54

3.5 Enforcement 58

3.6 Recent trends 65

3.7 Conclusions 69

Chapter 4 Trade Tools: holding the fort 72 or declaring open house?

Steven McGuire

4.1 Introduction 72

4.2 The instruments of trade policy 73

4.3 Liberalisation and protection in the IPE 75

4.4 European Union trade policy and 77 competitiveness

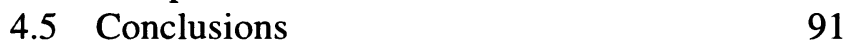

Chapter 5 Export Promotion: gaining 93 advantage through credit and insurance Günter Walzenbach

5.1 Introduction 93

5.2 National systems of export promotion $\quad 97$

5.3 The regulatory framework of the 102 European Union

5.4 Promoting exports in a changing 107 international economic environment

5.5 Conclusions 112 
Chapter 6 EU Business Taxation: fighting for competitiveness or combating competition? Claudio Radaelli

6.1 Introduction 114

6.2 EU tax policy: what has been done so far? 115

6.3 Tax policy and the behaviour of the $\quad 119$ multinational firm

6.4 If EU tax policy is the solution, what is the 124 problem?

6.5 The politics of EU corporate tax policy 126

6.6 Conclusions 131

Chapter 7 The choice of policies and the regulation 136 of public procurement in the $\mathrm{EU}$

Christopher Bovis

7.1 Introduction 136

7.2 The intellectual approach to public 138 procurement regulation

7.3 Public procurement and the policy choice 141 exercise

7.4 The regional policy dimension of public 142 procurement

7.5 The industrial policy dimension in public 147 procurement

7.6 The social policy dimension of public $\quad 150$ procurement

7.7 Conclusions

Chapter 8 European Transport Infrastructure: building for a competitive Europe

Debra Johnson and Colin Turner

8.1 Introduction

8.2 Transportation and international $\quad 160$ competitiveness

8.3 The nature of transport policy in the EU 163

8.4 The evolution of TENs policy 164 
8.5 Guidelines and priority projects $\quad 167$

8.6 Public-private partnerships 170

8.7 Financing public-private partnerships $\quad 172$

8.8 Evolving themes in European 176 infrastructure development

8.9 Conclusions

Chapter 9 Competing Through Human Capital: 181 training and education

Jill Preston

9.1 Introduction 181

9.2 Developments from the Treaty of Rome 185 to the TEU

9.3 Education and training as a horizontal 197 policy

9.4 Conclusions

201

Chapter 10 Promoting Competitiveness: inward 204 investment incentives and enterprise policy Thomas C. Lawton and Michael R. Hodges
10.1 Introduction
204
10.2 The process of inward investment
205
10.3 Promoting competitiveness through 207 inward investment
10.4 FDI as a competitive benchmark 209
10.5 Dowry chasing and investment decisions 210
10.6 The MAI and European inward 213 investment policies
10.7 The development of European enterprise 213 policy
10.8 Improving the SME business environment 215
10.9 Venture capital: the competitive catalyst 219
10.10 Conclusions 
Chapter 11 Conclusions: shaping the European 226 business environment

Thomas C. Lawton

11.1 The arguments revisited 226

11.2 Lessons for European integration and 227 competitiveness

11.3 Venture capital: falling short of the target 234

11.4 Putting the pieces together 234

11.5 Protecting or promoting competitiveness? 235

11.6 Challenges remaining 236

Bibliography 239

Index 259 


\section{List of figures}

1.1 WEF Measures of Competitiveness 6

1.2 Title XIII: Industry, Article $130 \quad 13$

1.3 EU industrial policy objectives 14

1.4 Instruments of European industrial competitiveness 18 policy

2.1 The main strands of European technology policy 24

2.2 Changes in R\&TD priorities between Framework 30 Programmes

2.3 Resource concentration for Framework V (1998-2002) 31

3.1 Consten and Grundig 53

3.2 Merger control 61

4.1 EC anti-dumping actions, 1990-7 87

4.2 Dispute settlement procedures involving the EU 89

7.1 Factors limiting SME involvement in the European 144 public procurement market

8.1 Transport and the operation of the enterprise 161

8.2 The Internationalisation of Transport Infrastructures 162

8.3 Progress on 14 Transport Priority TENs (end 1997) 169

9.1 European human capital inadequacies 183

9.2 EU training and education objectives 184

9.3 European structural fund objectives 188

9.4 Aspects of the 1998 ESF Budget (ECUs) 194

10.1 Criteria for SME status in the EU 214

10.2 EU priority actions for SMEs 216 


\section{Foreword}

This book seeks first of all to develop a clear and comprehensive definition of modern industrial policy. It examines the formulation and execution of industrial policy by the European Union (EU) and discusses how this has, or has not, contributed to the promotion of European competitiveness. This leads on to a critical analysis of specific instruments of industrial policy. Altogether, this is a book which poses difficult questions about EU policies and their practical impact on firms.

The unique feature of this book is its clear conceptualisation of European industrial competitiveness policy. This is the policy set which developed in the 1990s, comprising horizontal measures intended to facilitate structural adjustment and promote enterprise and corporate competitiveness. For the first time, the main instruments of this policy area are clearly delineated and comprehensively analysed. This approach differs from most previous works which focus on specific industrial sectors or countries. Lawton argues that there is no integrated, centrally co-ordinated industrial policy in the EU, rather a loose macroeconomic policy set does exist which, viewed collectively, does constitute what he terms 'a formidable assemblage of structural determinants of European competitiveness'.

This volume is not an apology for industrial policy nor a propaganda exercise on behalf of the EU. The progressive development of European industrial policy is lauded, as are the stated intentions of the EU's industrial competitiveness policy model. However, policy deficiencies and anticompetitive practices are clearly and, at times, strongly denunciated. Government and EU involvement in business affairs and market competition is accepted as a fait accompli but not as a prevailing right and necessity. The authors are not arguing that government should have an elaborate set of policies which directly influence corporate activity and performance. Rather, they contend that such policies exist in all countries and have always done so, to a lesser or greater extent. Instead, the key debate is between vertical and horizontal policies: those which target specific industries or companies for financial or other assistance, versus those that support and strengthen the structural determinants of a competitive economy, such as human capital or transport infrastructure. Lawton's authors favour the latter, arguing that if government must be involved in deliberations on competitiveness, then it is best advised to do so in the role of facilitator or structural enhancer than as financier or economic manager. 
Unlike many previous books on the theme of European industrial policy and competitiveness, this volume devotes particular attention to policies for small and medium-sized enterprises (SMEs) and the role which SMEs play in the development of an enterprise culture and the enhancement of economic competitiveness. This is a step in the right direction, shifting the policy emphasis away from over-assisted large and transnational enterprises and towards start-ups and relatively young enterprises in need of legal and structural support.

A multidisciplinary approach is adopted in this work. Legal, economic, management, and political science concepts are utilised and approaches that combine the academic and the practitioner. Overall, it is a study of public policy and therefore emphasis rests upon the management and impact of governmental strategies for industrial competitiveness. A basic knowledge of the EU's structure, institutional dynamics and policy-making process is presumed, as is some familiarity with basic economic concepts and business practices. This book takes the reader towards a detailed understanding of what constitutes modern industrial policy in Europe and how it affects the global competitiveness of companies and countries. As such, it should prove of interest to students of European studies, international business, and international political economy. In other spheres, European Industrial Policy and Competitiveness will be of interest to all those involved in or affected by industrial policy. These would include business people, interest groups, and policy-makers at both a national and EU level. This text is of relevance also beyond the confines of Europe. All of the policy instruments discussed are employed by governments in North America, East Asia, Latin America and elsewhere. Valuable comparative lessons can be drawn from the European experience in many disparate regions of the world.

This work clarifies and explains a set of important policy instruments of relevance to both states and firms in today's global economy. It also stimulates debate on the ways and means of shaping that elusive notion of 'European competitiveness'. For these reasons in particular, it is worthy of closer inspection and careful digestion.

\author{
Susan Strange \\ University of Warwick \\ September 1998
}




\section{Acknowledgements}

There are numerous institutions and individuals who have helped us to realise this work. In particular, I am indebted to the School of Management at Royal Holloway University of London for funding a workshop in April 1998 which brought us all together, clarified the book's overall themes and objectives, and cemented individual commitment. My thanks also to the University Association for Contemporary European Studies (UACES) for sponsoring a roundtable conference at King's College London in late November 1998, based on this volume's structure and themes.

I could not have found a better group of people to work with on this project. Their enthusiasm and commitment were unfailing and their good spirits infectious. A special word of thanks to Wolf Sauter for his contribution. He and I have been discussing these issues for a good many years and his input has been instrumental to the book's realisation.

Susan Strange passed away shortly after completing the foreword for this volume. Her memory lives on in all of us who have been influenced by her work and touched by her indomitable and benevolent character.

Sincere thanks to the EU's Office of Official Publications for granting permission to reproduce official data in several chapters. Thank you also to Stephen Gosden, Directorate General XII of the European Commission for his co-operation and useful comments. Glenn Fong of the American Graduate School of International Management was gracious enough to read drafts of Chapters 1 and 2 and to provide important feedback. Sarah Brown, Isobel Munday and Gloria Hart of Macmillan Business were helpful and accommodating in their dealings and highly professional in their approach. Keith Povey proved a meticulous proof-reader of the book's final draft.

As ever, Kirstin Howgate was the main source of editorial assistance and emotional support whilst I worked on this book. To her, a heartfelt 'thank you'.

Sadly, one of our number did not manage to see this project through to its completion. Mike Hodges departed this life during the summer of 1998 and the world is a much duller place since his passing. Those who had the privilege of knowing him will attest to his intellectual fortitude, quick wit and magical turn of phrase, as well as his genuine warmth and humanity. We dedicate this book to him as a gesture of our enduring affection. 


\section{Glossary}

Adapt Programme EU training and management development for small companies

AIM

Alternative Investment Market

BCC

Business Communication Centre

BC-NET

Business Co-operation Network

BRITE/EURAM Basic research in industrial technologies for Europe/raw materials and advanced materials

CAA Civil Aviation Authority

CAG Competitiveness Advisory Group

CAP Common Agricultural Policy

CCP Common Commercial Policy

CCT Common Customs Tariff

CEC Commission of the European Communities

CEDEFOP European Centre for Development of Vocational Training

CEN European Committee for Standardization

CENELEC European Committee for Electrotechnical

Standardization

CEP

Common Energy Policy

CER

Closer Economic Relations

CET

Common external tariff

CFP

Common Fisheries Policy

CFSP

CI

Common Foreign and Security Policy

Community Initiative

CIS Commonwealth of Independent States

CM Common Market

CMEA Council for Mutual Economic Assistance

COM/COM DOC Commission Document

COMECON see CMEA

Comenius

EU programme for school partnerships

COMETT

Community programme in education and training for technology

CORDIS Community research and development service

COREPER Committee of Permanent Representatives

CORINE Co-ordination of information on the environment in

Europe 
COST

\section{CREST}

CRS

CSCE

CSF

CSTID

CTP

$\mathrm{CU}$

DAC

DG

DI

DRIVE

DTI

EASDAQ

EAGGF

EC

ECA

ECB

ECJ

ECO

ECOFIN

ECOSOC

ECSC

ECU

EDEM

EDF

EDP

EEA

EEICs

EFTA

EIB

EICs

EIF

EMCF

EMF

EMI

EMS

EMU
European co-operation on scientific and technical research

Scientific and Technical Research Committee

Computerised Reservation System

Conference on Security and Co-operation in Europe

Community Support Framework

Committee for Scientific and Technical Information and

Documentation

Common Transport Policy

Customs Union

Development Assistant Committee (OECD)

Directorate General

Divergence Indicator

dedicated road infrastructure for vehicle safety in Europe

Department of Trade and Industry

European Association of Securities Dealers Automated

Quotation

European Agricultural Guidance and Guarantee Fund

European Community

European Court of Auditors

European Central Bank

European Court of Justice

European Cartel Office

European Council of Ministers for Financial Affairs

Economic and Social Committee

European Coal and Steel Industry

European currency unit

European Defence Equipment Market

European Development Fund

European Defence Policy

European Economic Area

European Enterprise and Innovation Centres

European Free Trade Area

European Investment Bank

Euro-info Centres

European Investment Fund

European Monetary Co-operation Fund

European Monetary Fund

European Monetary Institute

European Monetary System

European Monetary Union or Economic and Monetary

Union

EP

European Parliament 
EPC

EPU

Erasmus

ERDF

ERM

ESCB

ESF

ESPRIT

EU

EUA

Euratom

EUREKA

EURO

EURONET

EVCA

FAST

FCO

FDI

FEER

Force Programme

FTA

GATT

GDP

GNP

IATA

IBRD

ICONE

IDA

IDO

IEA

IEM

IGC

IMD

IMF

IMPACT

IRIS

IRTE

ISIS
European political co-operation

European Political Union

European Community action scheme for the mobility of university students

European Regional Development Fund

Exchange-rate mechanism

European System of Central Banks

European Social Fund

European strategic programme for research and

development in information technology

Economic Union

European Union of Account

European Atomic Energy Commission

European Research Co-operation Agency

Post-EMU European Unit of Currency

Direct information access network for Europe (DIANE)

European Venture Capital Association

Forecasting and assessment in the field of science and technology

Foreign and Commonwealth Office

Foreign Direct Investment

Fundamental Equilibrium Exchange Rate

EU programme for continuing vocational education

Free Trade Area

General Agreement on Tariffs and Trade

Gross Domestic Product

Gross National Product

International Air Transport Association

International Bank for Reconstruction and Development

(World Bank)

Comparative index of national and European standards

International Development Association

Integrated development operation

International Energy Agency

International Energy Market

Intergovernmental conference

International Institute for Management Development

International Monetary Fund

Information market policy actions

Network of demonstration projects on vocational training for women

Integrated road transport environment

Integrated standards information system 
xx Glossary

IT

I-TEC

Information Technology

JEPs

JET

EU Fund for investment in innovative business

Joint European Projects

JHA

Joint European Torus

JRC

Judicial and Home Affairs

Leonardo da Vinci EU funding for vocational training

Lingua

$\mathrm{EU}$ action programme to promote foreign language

knowledge

MAI

Multilateral Agreement on Investment

MCA

Monetary compensatory amount

MEP

Member of the European Parliament

MERM

Multilateral exchange rate model

MFT

Multilateral free trade

MISEP

Mutual information system on employment policies

MITI

Ministry for International Trade and Investment

MNC

MONITOR

Multinational Corporations

MTF

Research programme on strategic analysis, forecasting and assessment in research and technology

NATO

Merger Task Force

NCI

NETT

North Atlantic Treaty Organisation

New Community Instrument

NGO

NIC

Network for environmental technology transfer

Non-government organisation

NIE

NIEO

Newly industrialising country

Newly industrialising economy

NPCI

New International Economic order

NTB

National programme of Community interest

NTM

Non-tariff barrier

OECD

OEEC

OJ

PETRA

Non-tariff measure

Organisation for Economic Co-operation and Development

Organisation for European Economic Co-operation Official Journal (of the European Communities) Action programme for the vocational training of young people and their preparation for adult and working life

PHARE Poland and Hungary: Aid for the Reconstruction of Economies (this abbreviation subsequently retained for aid schemes to Eastern Europe as a whole)

PPP Polluter pays principle 
PPP

PTA

QMV

RACE

R\&D

R\&TD

$\mathrm{RCD}$

RECHAR

REGIS

RETEX

RIA

SAP

SAST

SCIENCE

SEA

SEC

SEM

SME

Socrates

SPD

SPERA

TACIS

TARIC

TEDIS

TEMPUS

TEN

TEU

TNC

TUC

UK

UN

UNCTAD
Public-private partnership

Preferential trade area

Qualified Majority Voting

Research and development in advanced communication technologies for Europe

Research and development

Research and technological development

Regional Co-operation for Development

EU retraining in coalmining areas

EU retraining funds for peripheral regions

EU retraining in textile areas

Regional impact assessment

Social action programme

Strategic analysis in the field of science and technology

Plan to stimulate the international co-operation and interchange necessary for European researchers

Single European Act

Internal Commission General Secretariat Document

Single European Market

Small and medium- sized enterprises

EU programme for educational exchange

Single Programme Documents

Support programme for a European assessment of research

EU economic aid programme to the nations of the former Soviet Union

Integrated Community tariff

Trade electronic data interchange systems

Trans-European Mobility Scheme for University

Studies

Trans-European Networks

Treaty on European Union

Transnational Corporations

Trade Union Congress

United Kingdom

United Nations

United Nations Conference on Trade and

Development 
xxii Glossary

UNCTC United Nations Centre for Trans-national Cooperations

UNESCO United Nations Educational, Scientific and Cultural

Organisation

UNIDO United Nations Industrial Development Organisation

URBAN EU retraining funds for metropolitan regions

UTR Unilateral tariff reduction

VAT Value-added tax

VER Voluntary export restraint

WEF World Economic Forum

VFM Value for money

WEU Western European Union

WTO World Trade Organisation

YES

'Youth for Europe' programme (youth exchange scheme) 


\section{Contributors}

Christopher Bovis is Professor of European Business Law at the University of Central Lancashire and Visiting Professor at the Queen's University of Belfast. He has advised the European Commission, national authorities, and industry on legal aspects of public procurement. His publications on the subject include EC Public Procurement Law (Longman-European Law Series 1997), Business Law in the European Union (Sweet \& Maxwell 1997), and The Liberalisation of Public Procurement and its Effects on the Common Market (Ashgate 1998).

Michael Hodges was Senior Lecturer in International Relations in the Department of International Relations and the Interdisciplinary Institute of Management Studies at the London School of Economics and Political Science. He has written extensively on European competitiveness and on international relations and multinational corporations. Dr Hodges also served as Consultant to the European Commission and as Special Adviser to the UK House of Lords Select Committee on the European Communities.

Debra Johnson is a Principal Lecturer in the Faculty of Business and Management at the University of Lincolnshire and Humberside. Before joining the university, she worked as a professional economist in the energy and transport sectors. She has published widely in the field of European business and integration, particularly in the areas of energy policy and transEuropean networks.

Thomas Lawton is Lecturer in European Business and Corporate Strategy at the School of Management, Royal Holloway University of London. He has been a visiting scholar at UC Berkeley and at INSEAD, and an EU HCM research fellow at the University of Essex. Dr Lawton has written on the nature and market effects of EU industrial policy and on European collaborative R\&D initiatives, including his book, Technology and the New Diplomacy (Avebury 1997). His research interests centre on European competitiveness, strategic management, and business-government relations.

Steven McGuire is Lecturer in International Management at the School of Management, Royal Holloway University of London. Previously, he was a research fellow at Loughborough University, having received his doctorate from Oxford University. His research interests centre on the role of firms in 
the development of trade and industrial policies for high technology industries. His publications include Airbus Industrie: Conflict and Cooperation in US-EC Trade Relations (Macmillan 1997) and (co-edited with Brian Hocking) International Trade Politics (Routledge 1999).

Jill Preston is Director of Research and Professor of European Integration at Anglia Business School, Anglia Polytechnic University, Cambridge. Dr Preston has broadcast and published widely on European issues. Her main areas of interest are EU policy for small firms, European training and education policy, and international implementation issues.

Claudio M. Radaelli is Lecturer in Comparative Public Policy in the Department of European Studies at Bradford University. A former EU Research Fellow and EUI Jean Monnet Fellow, Dr Radaelli has published on the public policy of the European Union, theoretical policy analysis, and Italian policy and politics. He is the author of The Politics of Corporate Taxation in the European Union (Routledge 1997) and Technocracy in the European Union (Longman 1999).

Wolf Sauter is Professor of Economic Law at the Rijksuniversiteit Groningen (The Netherlands). Dr Sauter was the founding managing editor of the European Law Journal and formerly practised European and comparative telecommunications law in Brussels with Weil, Gotshal and Manges. His past publications include Competition Law and Industrial Policy in the EU (OUP 1997) and current research interests focus on European competition law and regulation for multimedia convergence.

Colin Turner is Principal Lecturer in European Business at the University of Huddersfield. He has published in many areas of European business, particularly telecommunications and trans-European networks. He is the joint author (with Debra Johnson) of Trans-European Networks: the political economy of integrating Europe's infrastructure (Macmillan 1997).

G.P.E. Walzenbach is Lecturer in European Politics at the University of the West of England, Bristol. He holds a PhD from the European University Institute and was a post-doctoral ESRC Research Officer at Nuffield College, Oxford, working on West European Core Executives. Dr Walzenbach has published on comparative public policy and German policy towards the EU and is the author of Co-ordination in Context: Institutional Choices to Promote Exports (Ashgate 1998). 